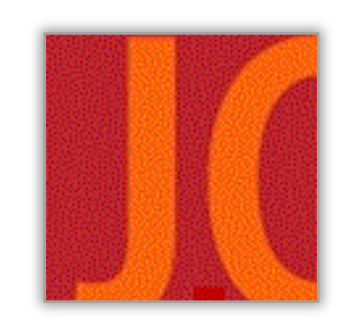

\title{
Book Review: Understanding the School Curriculum: Theory, Politics and Principles
}

\author{
Daeyoung Goh \\ University of British Columbia
}

\begin{abstract}
:
Alex Moore's (2015) Understanding the School Curriculum: Theory, Politics and Principles explores how the school curriculum works through its becoming as it navigates reproductive paranoia and (r)evolutionary schizophrenia. Moore suggests that the school curriculum inevitably intersects with political and socio-economic interests as well as the globalization movement. In this light, the book stimulates the reader to ponder questions such as, "Who decides what kind of knowledge we should have in this wider, ever-changing world?" and "How have issues around knowledge developed with the school curriculum?" and "What sort of future could educators imagine for alternative knowledge, educational practice and society?" Such questions haunt the book, while promoting the educator and the learner to risk weaving a creative becoming and thereby moving the realm of knowledge from the boundary of instrumental rationality to the progressive dynamics of humanity.
\end{abstract}

Keywords: curriculum studies; curriculum theory; knowledge; repair curriculum; curriculum dynamikos 


\title{
Recension : \\ Understanding the School Curriculum : Theory, Politics and Principles
}

\begin{abstract}
Résumé :
Understanding the School Curriculum : Theory, Politics and Principles (Comprendre le programme scholaire : theorie, politique et principes) d'auteur Alex Moore (2015) explore la façon dont le programme scolaire fonctionne à travers son devenir entre la paranoïa reproductive et la schizophrénie de (r)évolution. Moore suggère que le programme scolaire interfère inévitablement aussi bien avec les intérêts politiques et socio-économiques qu'avec le mouvement de la globalisation. Dans cette optique, le livre incite le lecteur à réfléchir aux questions telles que : "Qui décide du genre de connaissances que nous devrions posséder dans ce monde en perpétuelle évolution ? » et "Comment les problèmes liés aux connaissances se sont-ils développés avec le programme scolaire ? » et «Quelle sorte de futur les éducateurs pourraient imaginer pour des connaissances alternatives, une pratique pédagogique et la société ? " Le livre regorge de telles questions tout en encourageant les éducateurs et les apprenants à prendre le risque de tisser un devenir créatif et de déplacer ainsi le domaine de la connaissance de la frontière de la rationalité instrumentale à la dynamique progressive de I'humanité.
\end{abstract}

Mots clés : étude de programme; théorie de curriculum; connaissance; curriculum de la réparation; curriculum dynamikos 


\section{Book Review}

Moore, A. (2015). Understanding the school curriculum: Theory, politics and principles. Routledge.

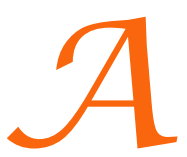
lex Moore's Understanding the School Curriculum: Theory, Politics and Principles reflects on a potential transition of Western and global school curriculum from autocracy to democracy. Moore, emeritus professor of education at the Institute of Education, University College London, maintains that at a time of rapid social change, we need to question the rationales for school curricula and their underlying mechanisms and processes: Who decides what sort of society is and will be possible and desirable? How has it been related to issues regarding knowledge? The book has nine chapters, including an introduction. The eight main chapters address the issue of "curriculum dynamikos" (Chapter 2), "the meaning of curriculum" (Chapter 3), "knowledge" (Chapter 4), "digital information and communications technologies" (Chapter 5), "globalization and curriculum 'internationalization'" (Chapter 6), "curriculum decision-making" (Chapters 7, 8) and "curriculum developments within the international context" (Chapter 9). Moore suggests that the chapters in his book could be read independently of one another because points across every section of the book reveal how instrumental technologies, such as competition, performativity and economic efficiency may cause tensions in the emergence of alternative curricula. Although Moore thoroughly examines the educational systems and policy agendas in England, UK, his arguments, supported by various theories, studies and cases, extend beyond the boundaries of particular locations, providing insights into the nature of political ideologies and globalization, as well as their effects on curriculum policy and practice. Specifically, Moore's noteworthy attention to the work of Deleuze and Guattari's (1977/2004) schizoanalysis of capitalism may bring the reader to refreshing realizations about a dynamic potential between paranoia, concerned with centralized, well-defined and governing reproductions, and schizophrenia, involved with "devolved", "interpretable" (Moore, 2015, p. 41) and progressive (r)evolution. ${ }^{1}$ As Moore appreciates the terms, paranoia and schizophrenia characterize two poles of school curriculum desire, the forces of preservation and of creative becoming, forces "that are in permanent tension" (p. 30).

Moore argues that the capitalist nation-states tend to choose curriculum content that produces usefulknowledge for the expansion of the national economy. He suggests that with the

\footnotetext{
${ }^{1}$ A note regarding the terms, schizoanalysis, paranoia and schizophrenia, as used, here: the terms do not refer to mental health conditions but are appropriations from the philosophic literature informing Moore. Deleuze and Guattari's "schizoanalysis" initially explored the broader capitalist socio-economic system. Specifically, "the free market of the private sector is presented by Deleuze and Guattari as predominantly 'schizophrenic,' while the State generally takes on a more regulatory 'paranoid' or 'repressive' character" (Moore, 2015, p. 30). Above all, "paranoia" and "schizophrenia" are not binary opposite concepts. Instead, they can be seen "as representing competing tendencies" because the characteristics of schizophrenia "might still require some degree of 'paranoid' regulation and repression in order for its dynamism to be sustained and in order for equity across the system to be ensured" (p. 40).
} 
increased mobility of digital information and communications technologies, economic freedom and competitiveness have become the yardstick for measuring the school curriculum and the impetus to redesign and reconfigure schooling. When a capitalist society establishes national economic growth as a benchmark for the school curriculum, the continuing interplay between the calculated administration and management of the school curriculum is in danger of becoming tethered with market-oriented comparison, measurement and examination techniques. Moore worries that in such a case, knowledge promoting original or experimental thinking is less welcomed than the predetermined "'safe' curriculum with its 'safe' knowledge" (Moore, 2015, p. 158) that accommodates such high-stakes testing and the preparations they entail.

The conception of safe knowledge and the safe school curriculum intimately mirrors a standardized curriculum designed to solve established problems, what Moore (2015) describes as a "repair curriculum" (p. 138). The rationales of such a curriculum derive their justification from the linear and positivistic "objectives-based approach" (Moore, 2015, p. 55), as elaborated by Tyler (1949) and, in a different sense, by Bobbitt's early works proposing the efficient management of the curriculum (1912, 1918/2012). They give specific prominence to disciplinary specialists' roles, as well as to learners' acquisition of prescribed knowledge. As Moore indicates, Tyler (1949) emphasized the triad of science, objectives and standards in determining the role of curriculum and instruction. His rationale, which still haunts school curricula across the world with the assistance of the centralized nation-state agencies, such as the Ministry of Education or the Department for Education, advocates a learning-goals-driven curriculum design that endorses scientific and efficiency-based management of school curricula. Predetermined knowledge, coupled with measurable outcomes, could be prioritized to solve fundamental economic problems, and accordingly, educators would become subject experts rather than learning facilitators. Conceived and practised in this way, education participants, including teachers, administrators, parents and students, have been/are given little room to exercise any meaningful alternative to the curriculum preplanned and informed by productivity and instrumentality.

As safe knowledge defines effective teaching and learning in line with an economic productivity calculation, it generates the sophisticated technology of biopolitical surveillance through practices of exclusion and normalization. The official curriculum may "serve to offer a particular 'comfortable' body of skills" (Moore, 2015, p. 154). This body of skills is composed of easily quantifiable skills, highlighting professional expertise and knowledge that disregard the irrational aspects of human nature and the asymmetrical power differentials in the social world. As a result, the "'neutral' forms of information and knowledge" (p. 99) and their exclusion of "'difficult,' 'challenging' knowledge in the curriculum" (p. 158) may readily be applied to different educational settings.

Defining knowledge as a fixed, unalterable and complete idea, based on managerial skill sets, ignores the magnitude of varied, risky and complex human experiences, which are often "ambiguous, context-bound, and beyond the power of science to predict with certainty" (Elliott, 2000, as cited in Moore, 2015, p. 9). Indeed, under the banner of curriculum neutrality, the principles of exclusion and normalization are smoothly articulated, acting as the primary modes of curriculum planning. In this 
way, "education [equating] to examination success and academic competition" (Atkinson, 2013, as cited in Moore, 2015, p. 79) could eventually hinder educators and learners from maintaining significant and reciprocal relationships. Given that instrumental intelligence is highly valued in a market-oriented society, the logic of comparison and competition has overwhelmingly pushed school practitioners, including educators and administrators alike, to be transparent but vacant and only recognizable by outstanding performances. This logic plays a dominant role in producing and encouraging conformist attitudes and behaviour towards those who assess their work and output. As such, school practitioners are never welcomed unconditionally; instead, they are objectified and alienated from their teaching and school administration through the impersonal standards of assessment. The instrumental rationality also streamlines formative evaluation of students' potential in conjunction with mandated standardized tests. Here, particular policymakers and administrative bureaucrats can homogenize the curriculum decision-making processes with ease to design accountable and responsibility-inducing models of the national school curriculum.

Moore indicates that digital information and communications technologies run the risk of worsening this biopolitical paranoia. First, he suggests that perpetual accessibility and dependency on disparate or unconnected facts cause "a dilution of genuine thinking and learning" (Moore, 2015, p. 102). In this instance, knowledge quickly turns into a repository of incoherent data, decreasing the learner's capacity to discern who controls information. Second, as digital technologies precede reciprocity in social interaction and command the public sphere, individuals are likely to indulge in private forms of pleasure through their digital devices. This self-absorption process prevents them not only from critically examining facts and information, but also from recognizing the multi-layered moments of the present, which cut through the past and corresponding changes in the future. In effect, an ahistorical understanding of the present may even strengthen social and personal prejudices in a way comparable to what McCormick and Murphy (2000) term a "mirror of reality" (as cited in Moore, 2015, p. 70). This mirror state is one in which individuals have difficulty allowing themselves to take up multi-dimensional relations and apply them to the given situation, as they are unaware of the unknown becomings. Above all, the subordination of untested information provided by digital platforms makes it hard to bring about a "cosmopolitan mindset" (Moore, 2015, p. 125). Nevertheless, people can also turn their attention to the possibilities afforded by each moment to take care of themselves and the locally and globally marginalized and disenfranchised. And if so, the cosmopolitan mindset would then involve thinking deeply about "the issue of 'who is in control here?'" (p. 103). In such a manner, democratic citizens have the potential to problematize an automatized world where the survival and well-being of individuals mainly rest upon their selfdirecting performativity and not upon public support or the welfare provision by the government.

Moore is keen to stress that competitive globalization intensifies international exclusion rather than international cooperation and a cosmopolitan turn in mutual understanding. According to Moore, education underpinned by "critical thinking and reflection" (Nussbaum, 2010); that is to say, "genuine" education (Ikeda, 2005) crafted from students' deliberate efforts to question local and global issues can facilitate democratic progress and inclusive citizenship, which "seek to change 
society through ... a sense of global moral responsibility" (Ahmad, 2010, as cited in Moore, 2015, p. 115). However, an overemphasis on global figures and data produced through measurable and quantifiable educational outcomes may neglect a significant aspect of teaching and learning, namely, the recurrent emotional and interactive experiences in education (Hargreaves, 1998). In this context, the "repair curriculum" (Moore, 2015, p. 138) has interrupted the process of democratic curriculum development, as it has been more exacerbated by "powerful, widespread neo-liberal and neoconservative discourses that emphasise and hegemonically normalise many of the values and practices that a global curriculum would need and seek to work against" (Bates, 2005, as cited in Moore, 2015, p. 117).

To move from a paranoia mode of intensified subjugation, Moore illustrates Deleuze and Guattari's idea of schizophrenia wherein manifold encounters with dissimilarity occur. It is through these tensions that the molecular- "'the little cracks' or 'imperceptible ruptures'" (Coleman \& Ringrose, 2013, p. 15)—activates the "curriculum dynamism" (Moore, 2015, p. 40). Moore sets off on his revolutionary journey by reflecting on Holland's analytical points to Deleuze and Guattari's AntiOedipus, implying that a "jazz-or ... jazz band" (p. 54) metaphor may have the power to complement the objectives-based curriculum approach. Unlike the measured assessment of the objectives model, the notion of jazz invents a space for pondering how seemingly disparate subjects' voices are able to achieve the curriculum dynamism in imaginative, dialogical and improvised ways. Then, just as jazz music accepts and derives numerous external and internal emotions as no less than integral parts of music-making, our feelings and experiences of anxiety, empathy, fear, grief, hostility, love, passion, pleasure, prejudice and sympathy, together with their relations to diverse school subjects, would all be allowed into no-matter-which classrooms, serving in the capacity of curriculum organisms worthy of our attention and appreciation. In other words, as improvised interactional synchrony (Sawyer, 2005), the school curriculum comes to be a medium for our desires, encouraging individual external vicissitudes of life to be connected with collective internal experiences of schooling and thereby guiding us into an "unrehearsed intellectual adventure" (Oakeshott, 1962, as cited in Moore, 2015, p. 98). This journey stimulates interaction from a variety of educational participants with distinct ideas and enables them to explore unfamiliar, intricate knowledge and create a dynamic milieu for the formation of both useful and powerful knowledge.

Nevertheless, just as space for new opportunities opens up, the centralized nation-state may regulate the process of devising the school curriculum in an effort to maintain the paranoid status quo. Moore thus, referring to Ruti's (2012) arguments, suggests that emotionality, unknowable possibilities and "the impossibility of a 'single history'" might be considered in imagining legitimate curriculum content so as not to lose sight of "a steady foothold in cultural narrative and other collective landmarks" (Ruti, 2012, as cited in Moore, 2015, p. 156). In effect, generating a creative dynamism between "useful" knowledge and "powerful" knowledge for progressive openness can be an ongoing curricular project to restore interactive teaching and studying. As teachers and students recover their desire for emotional sensibilities and cultural expressions, they do not need to find solace in the pre-selected facts and information alone. This exploration for "broad and balanced" 
(Moore, 2015, p. 53) curricula embraces a mode of collaborative relationships that shapes an intersubjective identity for teachers and students alike and transforms their vacant economic subjectivity into the (un)stable (dis)continuity of the original-primordial humanity.

Finally, Moore's points bring readers to a forgotten insight. It is crucial to value our faith in humanity, with the aim that we vitalize the dynamics of the curriculum, that is to say, "curriculum dynamikos" (Moore, 2015, p. 17). When schooling is estranged from human "feelings, emotions, or 'affect"' (p. 155), there is a danger of "reinforcing particular learner-teacher, child-adult hierarchical relationships" (p. 154). Likewise, as Hargreaves (1998) articulates, emotions are the kernel of educational phenomena as they decide the "most dynamic qualities" (p. 835) of teaching. Hargreaves (2000) specifically underscores that instantaneously occurring "emotional understanding" (Denzin, $1984 / 2007$, p. 127) founded on shared experiences and mutual respect is not possible without a change in education reformers' obsession with "curriculum consistency, testing processes, accountability measures and other technologies of control" (Hargreaves, 2000, p. 824) that may instead result in "the burden of cognitive content coverage in the classroom" (Moore, 2015, p. 825). When education disavows its potential for being different, a task-oriented, prescribed teaching model contributes to emotional estrangement between teachers and their students. Therefore, there is a need to contemplate and rethink educators' stance towards classical professionalism in favour of more "reciprocal partnerships with others" and "emotional understanding on which successful learning among and caring for all students depends" (Hargreaves, 2001, p. 1076).

Overall, Moore's analysis convincingly showed me that knowledge anchored in the methodological certainties, infatuated with instrumental rationality, should not be the sole basis of the school curriculum. The school curriculum is always in transition as an evolving "subject-yet-tocome" (Atkinson, 2013, as cited in Moore, 2015, p. 165), or subject-never-to-come, exploring the possibilities of transformation in this ever-changing social world with its dynamic potential. Viewed in this light, I was encouraged to envisage more schizophrenic spaces in which mutually dependent education creators and participants spontaneously make efforts to acknowledge, interpret and reshape their problems and needs with the expressions of humane emotions and responses. Moore's overarching point for me was not so much to deny overwhelming fears and struggles resulting from instrumental rationality as to recontextualize how standardized and normalized inner fantasies have gnawed at society. He asked me, as his other readers, to invigorate the dialogue about who/what should be the subjects/values of knowledge in deciding/weaving a dynamic and affective school curriculum that Tyler (1949) and the repair approach to education have overlooked for a long time.

\section{References}

Bobbitt, J. F. (1912). The elimination of waste in education. The Elementary School Teacher, 12(6), 259-271. https://doi.org/10.1086/454122

Bobbitt, J. F. (2012). The curriculum. Forgotten Books. (Original work published 1918)

Coleman, R., \& Ringrose, J. (2013). Introduction. In Deleuze and research methodologies (pp. 1-22). Edinburgh University Press. 
Deleuze, G., \& Guattari, F. (2004). A thousand plateaus: Capitalism and schizophrenia (B. Massumi, Trans.). Continuum. (Original work published 1977)

Denzin, N. K. (2007). On understanding emotion. Routledge. https://doi.org/10.4324/9781315125718 (Original work published 1984)

Hargreaves, A. (1998). The emotional practice of teaching. Teaching and Teacher Education, 14(8), 835-854. https://doi.org/10.1016/S0742-051X(98)00025-0

Hargreaves, A. (2000). Mixed emotions: Teachers' perceptions of their interactions with students. Teaching and Teacher Education, 16(8), 811-826. https://doi.org/10.1016/S0742051X(00)00028-7

Hargreaves, A. (2001). Emotional geographies of teaching. Teachers College Record, 103(6), 10561080. https://doi.org/10.1111/0161-4681.00142

Ikeda, D. (2005). Foreword. In N. Noddings (Ed.), Educating citizens for global awareness (pp. ix-xii). Teachers College Press.

Moore, A. (2015). Understanding the school curriculum: Theory, politics and principles. Routledge.

Nussbaum, M. C. (2010). Not for profit: Why democracy needs the humanities. Princeton University Press.

Sawyer, R. K. (2005). Music and conversation. In D. Miell, R. Macdonald, \& D. J. Hargreaves (Eds.), Musical communication (pp. 45-60). Oxford University Press.

Tyler, R. W. (1949). Basic principles of curriculum and instruction. University of Chicago Press. 